\title{
TEO-EKOLOGI BERBASIS NILAI LOKAL DALAM CITA HUKUM MASYARAKAT SUMBAWA
}

\author{
Oleh : \\ Lahmuddin Zuhri*
}

\begin{abstract}
Pancasila (five basic principles) serves as the way of life of Indonesian people its first principle regulates the divine values and it is in line with kerik salamat (safety and blessing) which manifests the Islamic values in the cultures and custom in Sumbawa. Kerik salamat is Islamic values living in the society since it is a mirror of the ideal of cultural law of the society. In the nation spirit theory, a law should be born from the nation/society spirits. Good quality regulations should posses three basic principles: juridical, sociological, and philosophical. The value of kerik salamat from an Islamic epistemological dimension spreads in the whole life of the community so that their level of religiousity, karabat (kinship) and saling sating (respect one another) may be maintained sustainably by the people of Sumbawa. Kerik salamat as a norm of life in people of Sumbawa should be recognized and protected because it is a morror of the ideal of law of the people to maintain a harmony so that the value og kinship, and respect among the members of the people may be maintained to keep the oneness and togatherness and also the shame culture (ila). Thi guides them in a strong social tie and legal construction which is full of the values of kinship to keep the existence of the community, and the life pattern in line with the expectation of Gods blessings in the ideal of the law in the people of Sumbawa.
\end{abstract}

Kata Kunci: teo-ekologi, cita hukum, nilai local Sumbawa.

\section{Pendahuluan}

Masyarakat Sumbawa dengan filosofis "Kerik salamat, Tau ke Tana Samawa", ${ }^{1}$ memadukan nilai budaya (adat) dengan hukum Islam dalam makna ada pertalian yang utuh antara adat Sumbawa dengan hukum Islam, sehingga kedua sistem hukum itu telah lama berlangsung dalam masyarakat dan budaya Sumbawa, dalam pernyataan resmi Lambaga Adat Tanah Samawa (LATS) Adat tau samawa (masyarakat Sumbawa) adalah Adat barenti ko syara', syara'barenti ko Kitabullah, ini mengandung makna bahwa masyarakat Sumbawa, memelihara (memegang teguh) agama, maka secara otomatis juga memelihara (memegang teguh) adat, begitu pula sebaliknya, memilihara agama mengandung arti memelihara alam dan seisinya, dalam konteks keislaman bahwa manusia ditakdirkan untuk menjadi khalifah, yang berkewajiban mengelola dan memakmurkan bumi (alam semesta) secara bertanggung jawab.
Secarahistoris, masyarakat Sumbawayangmelihat adat budaya memiliki kesatuan yang utuh dan bulat dengan agama Islam, ini menunjukkan bahwa cita dan kesadaran hukum masyarakat sumbawa dalam kaitannya dengan kehidupan keislaman memiliki tingkat aktualitas yang berkesinambungan seperti adanya budaya yang mengedepankan musakara (musyawarah) dan tokal barema (duduk bersama) serta memohon petunjuk kepada orang yang dituangkan dan dihormati karena memiliki pemahaman yang mendalam tentang agama dan keilmuan yang lain, hal ini akhirnya terkristalisasi menjadi suatu tradisi. Sejalan dengan pandangan di atas, dalam analisis I Dewa Gede Atmadja ${ }^{4}$, mengemukakan setidaknya terdapat empat momentum "pembentukan hukum," yang akan berpengaruh terhadap proses pembentukan hukum, yakni: Momen idiil berupa kenyataan alamiah dan kemasyarakatan Sumbawa; konfigurasi adalah pandangan hidup dan filsafat hidup (nilai budaya Kerik salamat masya-

* Direktur Pusat Studi Hukum dan HAM Univ Samawa. Email: Lahmuddinzuhri@yahoo.com 
Masyarakat sumbawa adalah masyarakat agraris (petani-peternak), hukumnya harus sesuai dengan kenyataan yang ada dalam masyarakat agraris, yang hidup secara wajar, kerik salamat adalah norma dan nilai mereka mempunyai daya berlaku efektif dan tidak begitu banyak memerlukan pengerahan institusional untuk melaksanakannya. ${ }^{2}$ Kenyataan yang hidup dalam masyarakat sebagai dasar sosiologis, termasuk pula kecenderungan dan harapan masyarakat. Tanpa memasukkan faktor-faktor kecenderungan dan harapan maka peraturan perundangundangan hanya sekedar merekam seketika. Keadaan seperti ini akan menyebabkan kelumpuhan peranan norma dan hukum. Hukum akan tertinggal dari dinamika masyarakat. Bahkan peraturan perundangundangan akan menjadi konservatif karena seolaholah pengukuhan kenyataan yang ada. Hal ini bertentangan dengan sisi lain dari peraturan perundangundangan yang diharapkan mengarahkan perkembangan masyarakat. ${ }^{3}$

rakat sumbawa); Momen politik, berupa aspirasi dan kebutuhan riil masyarakat (tuntutan masyarakat akan pengelolaan tanah Lar bernasik nilai kearifan lokal Kerik salamat yang berpihak kepada eksistensi komunitas, budaya dan ekologi sumbawa, yang konfigurasinya adalah kepentingan dan tujuan kebaikan alam dan masyarakat Sumbawa (tau ke tana samawa); Momen normatif, konfigurasinya adalah cita hukum, nilai-nilai dan asas-asas hukum; Momen tehnik, konfigurasinya adalah teknik perundangundangan"s.

Nilai Kerik Salamat dari dimensi epistemologi keislaman menyebar di seluruh kehidupan masyarakat sehingga religiusitas, karabat (kekeluargaan) dan saling satinggi (saling memuliakan) yang kuat akan dipertahankan secara berkesinambungan oleh masyarakat sumbawa. Kerik Salamat sebagai norma yang hidup dalam masyarakat Sumbawa harus mendapatkan pengakuan dan perlindungan karena merupakan cerminan norma keadilan, yaitu norma yang mengatur keharmonisan dalam masyarakat

\footnotetext{
${ }^{1}$ Kerik Salamat, Tau ke Tana Samawa merupakan falsafah hidup mastarakat sumbawa yang selalu mengharap Ridho ALLAH SWT, masyarakat sumbawa berkeyakinan selalu diawasi oleh ALLAH SWT selaku penguasa tungga semesta alam, sehingga nilai-nilai Ketuhanan selalu menjadi acuan dalam mengelola alam dan berintaraksi antar sesama, Kerik Salamat, Tau ke Tana Samawa memberikan landasan moral dan filosofis bagi kehidupan masyarakat masyarakat sumbawa menuju kebehahan (Kerik) dan keselatan (salamat) bagi masyarakat (tau) dan alam (tana) sumbawa

${ }^{2}$ Bagir Manan dalam Yuliandri. Op.Cit, hlm 135

${ }^{3}$ Ibid
}

dapatkan pengakuan dan perlindungan karena merupakan cerminan norma keadilan, yaitu norma yang mengatur keharmonisan dalam masyarakat sehingga terjaga nilai kekerabatan dan saling menghormati antar sesama anggota masyarakat, dengan tujuan untuk menjaga keutuhan dalam kebersamaan. Secara sosiologis, keseharian masyarakat Sumbawa adalah sebuah keluarga besar yang terbangun dari pola komunikasi berdimensi kekeluargaan dan kesederhanaan, yang menuntun mereka dalam ikatan sosial yang kuat, begitu juga kontruksi hukum yang terbangun, kental dengan nilai kekeluargaan guna menjaga eksistensi komunitas, menjaga nilai-nilai kekerabatan, dan bangunan hukum yang ada adalah manipestasi dari keperdayaan dan pola hidup keseharian mereka dalam mengelola alam sebagai petani dan peternak.

\section{Kajian Pustaka}

\section{1. Ekologi dalam tiga sisi (Manusia, Alam dan Tuhan)}

Ekologi adalah ilmu pengetahuan yang mempelajari hubungan timbal balik antara makhluk hidup dengan lingkungannya. Ekologi berasal dari kata Oikos berarti rumah atau "tempat hidup"\% (kemudian diartikan dengan rumah tangga). Dan Logos berarti ilmu pengetahuan. Ekologi berarti ilmu tentang makhluk hidup dalam rumahnya, atau ilmu tentang rumah tangga makhluk hidup ${ }^{7}$. Atau dapat juga dikatakan Ekologi adalah ilmu pengetahuan tentang hubungan antara organisme dan lingkungannya ${ }^{8}$.

Ilmu ekologi pertama kali dipergunakan seorang biolog bangsa Jerman Ernst Haecket pada tahun $1869^{9}$ Pada waktu itu ilmu ekologi dijadikan sebagai cabang dari ilmu biologi. Menurut Haeckel, ilmu ekologi diartikan sebagai keseluruhan pengetahuan yang berhubungan dengan relasi atau kaitan secara total antara organisme dengan lingkungannya yang bersifat organik maupun anorganik ${ }^{10}$.

\footnotetext{
${ }^{4}$ I Dewa Gede Atmadja, Asas-Asas Pembentukan Produk Hukum, Fakultas Hukum Universitas Udayana, tanpa tahun, hlm. 6-7

${ }^{5}$ Ibid hal 8

${ }^{6}$ Naniek Suparni, Pelestarian, Pengelolaan, dan Penegakan Hukum Lingkungan, (Jakarta : Sinar Grafika, 1994), h. 3

${ }^{7}$ Otto Soemarwoto, Ekologi, Lingkungan Hidup dan Pembangunan, (Jakarta : Penerbit Djambatan, 1994), h. 22 - 23

${ }^{8}$ S.J. Mc.Naughton dan Larry L. Wolf, General Ecology, (Saunders College Publishing, Second Edition, 1973), p. 15

${ }^{9}$ Moestadji, Pelestarian Kemampuan Lingkungan Hidup, (Jakarta Kejaksaan Agung RI, 1988), h. 3

${ }^{10}$ N.H.T. Siahaan, Hukum Lingkungan dan Ekologi Pembangunan, (Jakarta : Erlangga, 2004), h. 16
} 
sumbawa dapat menjaga keteraturan ekosistem dan komponen-komponen ekosistem satu dengan yang lainnya sesuai dengan fungsinya agar dapat bekerja dengan baik, sesuai mekanisme alam. Berbedanya cara pandang penguasaan dan pengelolaan terhadap sumber daya alam (SDA), menyebabkan terjadi ekploitasi terhadap SDA tersebut tanpa memperhatikan daya dukung dan kelestarian ekologi dan ekosistem yang ada. Pembangunan yang berpusat pada pertumbuhan ekonomi semata, sehingga pola pengelolaan SDA lebih dilihat sebagai sarana ekonomi ketimbang anugerah Tuhan atas kekayaan ekologi dan sosial dalam masyarakat sumbawa ${ }^{11}$.

Tulisan ini dilakukan untuk mencermati dan memaknai bagaimana nilai dan pola-pola prilaku masyarakat Sumbawa dalam pamanfaatan dan pengelolaan SDA, sehingga kedepan produk kebijakan daerah dapat memposisikan manusia selaku subjek hukum secara bertanggung jawab dan memperhatikan keberlanjutan ekologi, mengelola SDA kedepan harus memperhatikan nilai dan etika yang ada, yang sudah diwariskan oleh leluhur bangsa masyarakat Sumbawa, lewat adat dan kearifan lokal.

Dalam tulisan ini, konsep ekologi atau ekosistem yang menjadi fokus utama adalah ekosistem daratan area pertanian dan pengembalaan. Ekosistem data tersebut akan terjadi keseimbangan dan terjaganya keteraturan ekosistem, apabila hubungan antara komponen-komponen ekosistem satu dengan yang lainnya sesuai dengan fungsi dan bekerja dengan baik. Namun apabila salah satu komponen ekosistem misalnya seperti tanah, rusak akibat alih fungsi lahan dan pemanfaatan yang berlebihan. Penulis berpandangan bahwa perlu adanya transformasi nilai kerik salamat dalam peraturan daerah atau kebijakan daerah sebagai landasan hukum perilaku masyarakat sumbawa dalam mengelola lingkungan (tanah) guna menjaga kelestarian lingkungan (ekologi) yang berkelanjutan.

\section{2. Teo-Ekologi}

Pembangunan Kabupaten Sumbawa bukan hanya untuk mencapai kesejahteraan untuk kemajuan dan kemandirian, tetapi juga untukmewujudkan keadilan. Sebagai pelaksana dan penggerak pem-

${ }^{11}$ Lahmuddin Zuhri. Perlindungan Hak-Hak Masyarakat Atas Sumber Daya Alam (SDA) di Kabupaten Sumbawa. Jurnal Hukum Prasada. Program Magisrel Ilmu Hukum Pascasarjana Universitas Warmadewa. Dempasar. Vol 3. No 1. Hal 1-21. September 2015 bangunan sekaligus objek pembangunan, rakyat mempunyai hak, baik dalam melaksanakan maupun dalam menikmati hasil pembangunan. Pembangunan haruslah dilaksanakan dari rakyat, oleh rakyat, dan untuk rakyat. Oleh karena itu, masalah keadilan dan kelestarian lingkungan merupakan ciri utama dalam cita hukum masyarakat sumbawa.

Keadilan ini harus tercermin pada semua aspek kehidupan, yang mana semua rakyat mempunyai kesempatan yang sama dalam meningkatkan taraf hidupnya dan memperoleh lapangan pekerjaan, mendapatkan pelayanan sosial, pendidikan dan kesehatan, mengemukakan pendapat dan melaksanakan hak politiknya, serta perlindungan dan persamaan di depan hukum, tidak ada diskriminasi dalam bentuk apapun baik antarindividu, gender, dan wilayah. Kesejahteraan juga terkait dengan terwujudnya kesalehan individu dan sosial dalam kehidupan masyarakat Tana Samawa. Dengan demikian masyarakat "Nyaman Nyawe" merupakan masyarakat yang maju dan sejahtera.

Dalam tulisan ini lebih fokus pada kajian ekologi dan cita hukum masyarakat sumbawa, yang mana konsepsi kesejahteraan dalam masyarakat Sumbawa memiliki tiga dimensi, yakni dimensi kesejahteraan ekonomis dan kedamaian (senap semu), kesejahteraan sosial (riam remo) dan kesejahteraan spritual (Mura era). Cita hukum masyarakat sumbawa yang terbangun dari nilai kekeluargaan dan semangat kelestarian lingkungan, menjadi modal utama dalam pembangunan hukum. Nilai ini dimaknai, dihayati dan dijadikan pedoman bersama dalam kehidupan masyarakat, semua ini mesti disertai oleh sikap rasional kritis dilandasi nilai-nilai spiritual, keimanan kepada Allah SWT sebagai pemilik dan penguasa tunggal atas semesta alam.

Nilai-nilai Ketuhanan inilah yang memahirkan semangat dan etika sosial dalam berintraksi dengan alam. Kalau Kuntowijoyo menggali nilai ketuhanan dari perspektifsosial dan politik, yang melihat dimensi agama pada kehidupan politik, ada hubungan simbiosis antara konsepsi "daulat Tuhan" dan "daulat rakyat" dalam satu kesatuan, yang disebut oleh Sartono Kartodirdjo dan Kuntowijoyo ${ }^{12}$ sebagai "teo-demokrasi".

${ }^{12}$ Konsep Teo-demokrasi, kekuasaan itu dibatasi oleh rakyat. Kekuasaan itu juga diawasi oleh rakyat, disamping diawasi oleh Tuhan, sehingga kekuasaan menjadi transparan yang panduan oleh nilai-nila 
Dalam politik dan demokrasi yang berketuhanan, Menurut Kuntowijoyo, Tuhan dan manusia harus dibaca dengan "satu" tarikan napas, karena itu ditulis dengan "teo-demokrasi"13. Berarti bahwa kekuasaan manusia adalah amanah Tuhan yang harus diemban dengan sungguh-sungguh. Penulis melihat dalam kontek ekologi masyarakat sumbawa jaga sangat kental dengan nilai-nilai Ketauhidan. Artinya ada tanggung jawab manusia (masyarakat sumbawa) kepada Tuhan terkait dengan cara pengelolaan alam.

Dalam tulisan ini saya menggunakan istilah TeoEkologi, artinya aktivitas pengelolaan alam dalam kehidupan masyarakat sumbawa yang selalu mengharap Ridho ALLAH SWT, sekaligus masyarakat sumbawa berkeyakinan juga selalu diawasi oleh ALLAH SWT selaku penguasa tunggal semesta alam. Panduan nilai-nilai Ketuhanan mengelola alam sebagai pemenuhan kebutuhan hidup ${ }^{14}$ memberikan landasan moral dan filosofis bagi kehidupan masyarakat masyarakat sumbawa.

\section{Metode Penelitian}

Penelitian ini tergolong dalam jenis penelitian Sosial empiris atau lazim disebut Penelitian Socio Research yaitu penelitian yang dilakukan untuk menelaah nilai dan kaidah yang ada dalam masyarakat sebagai suatu kekuatan sosial yang empiris. Penelitian ini dilakukan untuk mencermati dan memaknai secara komprehensif, bagaimana nilai dan pola-pola prilakumasyarakat Sumbawa dalam aktivitas pamanfaatan dan pengelolaan sumber daya alam.

Pendekatan yang digunakan dalam penelitian ini di sesuaikan dengan masalah yang peneliti kaji, penelitian ini menggunakan pendekatan sosio kultural. Pendekatan ini dilatarbelakangi oleh pemikiran, bahwa ekonomi tidak terlepas dari kehidupan masyarakatnya berupa nilai dan sikap/prilaku. Saling satingi merupakan nilai lokal budaya Sumbawa, berkaitan dengan penelitian ini, pengamatan adalah penting kepentingan untuk keperluan data dan analisis

Ketuhanan yang memberikan landasan moral dan filosofis dalan sistem berdemokrasi, lihat Yudi Latif, Negara Paripurna: Historisitas, Rasionalitas dan Aktualitas Pancasila, (Jakarta: Gramedia, 2011), hml 111-113

${ }^{13}$ ibid

${ }^{14}$ Mengelola alam/tanah dalam pemenuhan kebutuhan hidup sebagai petani dan petenak, alam/tanah sumber dan alat pemenuhan kebutuhan hidip masyarakat sumbawa (eksistensi mayarakat sumbawa). data ${ }^{15}$. Pengamatan terkait dengan pola kehidupan Teo-ekologimasyarakat sumbawa. Kemudian Analisa dan interpretasi dalam penelitian ini, berupa serangkaian proses mengatur urutan data, mengorganisasikannya suatu pola, kategori dan suatu uraian dasar, sesuai sumber, fungsi dan klasifikasi, menjadi suatu uraian atau prase, guna menemukan ide atau tema yang dapat dijadikan hipotesis ${ }^{16}$. Kemudian dalam melakukan interpretasi data, peneliti menghasilkan analisis yang baik guna menjelaskan data yang didapat, serta menemukan pola hubungan dari ide atau prase-prase yang ada, dalam bentuk uraianuraian diskriftif kualitatif ${ }^{17}$.

\section{Pembahasan}

Nilai-nilai Kerik salamat masyarakat sumbawa sebagai wujud wajah Islam dalam hukum adat Sumbawa, yang tergambar dari perlakuan, penghormatan dan perlindungan antara lain perlindungan terhadap agama, jiwa, akal, keturunan, kehormatan, harta dan lingkungan. Berdasarkan pada Teori Maqasid al-Syari'ah, adat budaya Sumbawa dengan filosofis Kerik salamat yang bertujuan menjaga eksistensi komunitas, eksistensi kelestarian alam, yang kesemuanya itu adalah untuk kemanfaatan bersama, guna mendapat keberkahan dan bermanfaat bagi kebutuhan hidup masyarakat Sumbawa.

Secara epistemologi yang mempunyai sumbangan besar bagi terbentuknya pandangan hidup, cita moral dan cita hukum dalam kehidupan sosio kultural masyarakat Sumbawa. Proses ini berjalan sesuai dengan tingkat pemahaman keagamaan masyarakat Sumbawa sehingga memantulkan korelasi antara nilai kerik salamat dan realitas sosial masyarakat Sumbawa, yang pada akhlaknya melahirkan norma fundamental bagi masyarakat Sumbawa. Budaya dan agama dalam masyarakat Sumbawa memiliki makna yang sangat penting, yang oleh masyarakat Sumbawa digunakan sebagai pedoman hidup, dalam kontek adat dan budaya juga merupakan sebagai salah satu sumberhukum masyarakat Sumbawa. Sehingga transformasi nilai kerik selamat dalam

\footnotetext{
${ }^{15}$ Sugioyono, Memahami Penelitian Kualitatif (Cet.7). (Bandung Alfa Beta, 2012, hlm 54

${ }^{16}$ L. J. Moleong, Metodologi Penelitian Kualitatif, (Bandung: Remaja Rasdakarya, 2000), hlm 103; Lihat juga Noeng Muhajir, Metodolog Penelitian Kualitatif, edisi III (Yogyakarta: Rake Sarasin, 1998), hlm 104

${ }^{17}$ L. J. Moleong, Ibid., hlm. 103.
} 
kebijakan daerah atau produk hukum daerah menjadi penting.

Peraturan perundang-undangan yang berkualitas, dapat dilihat dari tiga landasan dalam penyusunannya, yaitu: pertama, landasan yuridis; kedua, landasan sosiologis; dan ketiga, landasan filosofis. Pentingnya ketiga unsur landasan pembentukan peraturan perundang-undangan tersebut, agar peraturan perundang-undangan yang dibentuk, memiliki kaidah yang sah secara hukum (legal validity), dan mampu berlaku efektif karena dapat atau akan diterima masyarakat secara wajar, serta berlaku untuk waktu yang panjang.

Senada dengan Begir Manan, Menurut Jimly Asshiddiqie ${ }^{18}$ membawa landasan administratifdan politik, berkaitan landasan pembentukan peraturan perundang-undangan, dengan melihat dari sisi teknis pembentukan undang-undang, landasan pembentukan undang-undang haruslah tergambar dalam "konsiderans" suatu peraturan perundang-undangan. Dalam konsiderans suatu undang-undang haruslah memuat norma hukum yang baik, yang menjadi landasan keberlakuan bagi undang-undang tersebut, yaitu terdiri dari:

Pertama landasan filosofis, Undang-undang selalu mengandung norma-norma hukum yang diidealkan (ideal norms) oleh suatu masyarakat ke arah mana cita-cita luhur kehidupan bermasyarakat bernegara hendak diarahkan. Kedua landasan sosiologis, bahwa setiap norma hukum yang dituangkan dalam undang-undang haruslah mencerminkan tuntutan kebutuhan masyarakat sendiri akan norma hukum yang sesuai dengan realitas kesadaran hukum masyarakat. Ketiga landasan politis, Bahwa dalam konsiderans harus pula tergambar adanya sistem rujukan konstitusional menurut cita-cita dan norma dasar yang terkandung dalam UUD 1945 sebagai sumber kebijakan pokok atau sumber politik hukum yang melandasi pembentukan undang-undang yang bersangkutan. Keempat landasan yuridis, Dalam perumusan setiap undang-undang, landasan yuridis ini haruslah ditempatkan pada bagian konsiderans "Mengingat." Kelima landasan administratif, dasar ini bersifat "fakultatif" (sesuai kebutuhan), dalam pengertian tidak semua undangundang mencantumkan landasan ini, dalam teknis pembentukan undang-undang, biasanya landasan dimasukkan dalam konsiderans "Memperhatikan". Landasan ini berisi pencantuman rujukan dalam hal adanya perintah untuk mengatur secara administratif ${ }^{19}$. Jika kelima landasan tersebut terpenuhi dalam setiap proses dan substansi pembentukan perundangundangan, kiranya keseluruhan undang-undang yang dihasilkan, menjadi undang-undang yang baik, berkualitas, dan berkelanjutan.

Pada pembahasan ini, peneliti akan membuktikan bahwa kerik salamat layak untuk ditransformasikan menjadi hukum yang dicita-citakan oleh masyarakat Sumbawa, dengan tiga faktor pembuktian:

1. Landasan filosofis, substansi normatifnilai-nilai kerik salamat dalam masyarakat dan budaya Sumbawa melahirkan sikap epistemologi yang mempunyai sumbangan besar bagi terbentuknya pandangan hidup, cita moral dan cita hukum dalam kehidupan sosio kultural masyarakat Sumbawa yang melihat alam adalah amanat Tuhan yang harus dijaga kelestariannya. Proses ini berjalan sesuai dengan tingkat pemahaman keagamaan masyarakat Sumbawa sehingga memantulkan korelasi antara nilai kerik salamat dan realitas sosial masyarakat Sumbawa, yang pada akhlaknya melahirkan norma fundamental bagi masyarakat Sumbawa.

2. Landasan sosiologis, sejarah masyarakat Sumbawa yang melihat agama memiliki satuan yang utuh dan bulat dengan agama Islam, ini menunjukkan bahwa cita dan kesadaran hukum dalam kaitannya dengan kehidupan keislaman memiliki tingkat aktualitas yang berkesinambungan seperti adanya mekanisme pengelolaan alam (sawah ladang) secara baik dan bertangung jawab yang memperhatikan daya dukung lingkungan, serta budaya menjaga ata air bagi kehidupan ternak mereka. hal ini terkristalisasi menjadi suatu tradisi. Akibatnya, saat ini, dimensi lain pengaruh epistemologi keislaman menyebar sampai aspek kehidupan sehingga tingkat religiusitas, dalam pengelolaan alam adalah berkah yang harus dijaga kesinambungan.

3. Landasanyuridis, dalam Pancasila, sila pertama yang mengatur tentang nilai-nilai keTuhanan, hal ini selaras dengan nilai kerik salamat adalah manifestasi dari nilai Islam dalam wajah budaya dan adat Sumbawa. Kemudian dalam Undangundang Dasar Negara Republik Indonesia Tahun 1945 yang menujukkan bahwa nilai-nilai lokal, nilai-nilai agama dan keyakinan dilindungi dan diakui keberadaannya. 
Memperhatikan ketiga faktor, di atas, pada dasarnya transformasi nilai-nilai kearifan lokal kerik salamat dapat dibentuk oleh prilaku dalam masyarakat dan kebudayaan Sumbawa, untuk memberikan kekuatan hukum terhadap perlindungan nilainilai kerik salamat sebagai sarana penyelesaian konflik pengelolaan lingkungan (sawah ladang) dari hasil kajian peneliti memandang perlu nilai lokal kerik salamat diatur dalam sebuah peraturan perundang-undangan dalam bentuk Peraturan Daerah.

Berkaitan dengan cita hukum masyarakat yaitu apa yang mereka harapkan dari hukum, misalnya untuk menjamin keadilan, ketertiban, kesejahteraan dan sebagainya ${ }^{20}$. Cita hukum (rechtsidee) tersebut tumbuh dari sistem nilai mereka mengenai baik atau buruk, pandangan terhadap hubungan individual dan kemasyarakatan, tentang kebendaan dan lain sebagainya. Hukum diharapkan mencerminkan sistem nilai tersebut baik sebagai sarana yang melindungi nilai-nilai maupun sebagai sarana mewujudkannya dalam tingkah laku masyarakat. Nilai-nilai yang ada dalam masyarakat sebagai gambaran masyarakat Sumbawa, sehingga setiap pembentukan hukum atau peraturan perundang-undangan harus dapat menangkapnya setiap kali akan membentuk hukum atau peraturan perundang-undangan.

Cita hukum dalam pandangan kerik salamat masyarakat sumbawa, dalam kacamata terminologi hukum islam memformulasikan al-'adah muhakkamah (adat menjadi dasar penetapan hukum) dengan perasyarat adat tersebut tidak bertentangan dengan Al-Quran dan Sunah, dengan syarat: adat tersebut harus secara umum dipraktikkan oleh masyarakat atau sebagian tertentu dari masyarakat; Adat harus menjadi kebiasaan pada saat ditetapkan sebagai rujukan hukum; Adat batal tak kala bertentangan dengan sumber utama hukum Islam yaitu Al-Qur'an dan Al-Hadist; Jika terjadi perselisihan, adat akan diterima sebagai sumber hukum jika tidak ada pihak yang menolak adat tersebut ${ }^{21}$.

Masyarakat Sumbawa dengan filosofis "Kerik salamat, Tau ke Tana Samawa", memadukan nilai budaya (adat) dengan hukum Islam dalam makna ada pertalian yang utuh antara adat Sumbawa dengan hukum Islam, sehingga kedua sistem hukum itu telah

\footnotetext{
${ }^{20}$ Bagir Manan dalam Yuliandri. Op.Cit, hlm 135-136

${ }^{21}$ Abdul Wahab Khallaf, Kaidah-Kaidah Hukum Islam. (Bandung Risalah, 1984), hlm 132-135
}

lama berlangsung dalam masyarakat dan budaya Sumbawa, dalam konteks keislaman bahwa manusia ditakdirkan untuk menjadi khalifah, yang berkewajiban mengelola dan memakmurkan bumi (alam semesta) secara bertangung jawab. Aktivitas tau samawa (masyarakat/orang Sumbawa) atau siapapun yang berada pada tana samawa (wilayah Sumbawa) harus dilaksanakan dengan mengedepankan adat-istiadat dan nilai agama tau samawa (agama Islam). Adat (urf) adat dan Sumbawa, ini mempunyai peran signifikan dalam proses penciptaan hukum. Pandangan dan perlakuan masyarakat Sumbawa terhadap lingkungan hidup, dapat dijadikan sumber nilai dalam memberikan sumbangan pemikiran sebagai upaya penyelenggaraan pembangunan yang lebih mempertimbangkan pelestarian lingkungan hidup di Kabupaten Sumbawa khususnya dan Indonesia pada umumnya.

Sejalan dengan apa yang dijelaskan fiqh lingkungan hidup, Pentingnya perlindungan hukum terhadap lingkungan termasuk pada salah dan ladang yang ada di Kabupaten Sumbawa dapat ditinjau berdasarkan instrumen maqasid al-syariah yaitu jaminan perlindungan terhadap lingkungan hidup atau yang disebut oleh Ali Yafie dengan istilah hifdzu al-bi'ah. Hifdzu al-bi'ah adalah pemeliharaan dan perlindungan terhadap lingkungan hidup, sehingga penanganannya perlu diletakkan di atas suatu pondasi moral, untuk mendukung upaya penyelamatan lingkungan. Fiqh lingkungan berupaya menyadarkan manusia yang beriman supaya menginsafi bahwa lingkungan hidup tidak bisa dilepas dari tanggung jawab manusia sebagai amanah dari Allah SWT yang harus di emban ${ }^{22}$.

Hal inilah yang kemudian menjadi tujuan syari'at/ agama (maqashid al-syari'ah) yang dibawa oleh Rasullullah SAW, yakni penataan hal ihwal manusia dalam kehidupan duniawi dan ukhrawi, ${ }^{1}$ dengan empat hal dasar, yaitu :

1. Rub'u al-Ibadat, yaitu bagian yang menata hubungan antara manusia selaku makhluk dengan Allah SWT sebagai khaliqnya, yakni hubungan transedensi.

2. Rub 'u al-Mu'amalat, yaitu bagian yang menata hubungah manusia dalam lalu lintas pergaulannya

${ }^{22}$ Ali Yafie, Merintis Fiqh Lingkungan Hidup, (Jakarta: Ufuk Press, 2006), hlm 161 
dengan sesama untuk memenuhi hajat kehidupannya sehari-hari.

3. Rub'ual-Munakahat, yaitu bagian yang menata hubungan manusia dalam lingkungan dan keluarga.

4. Rub'u al-Jinayat, yaitu bagian yang menata pengamanan manusia dalam suatu tertib pergaulan yang menjamin keselamatan dan ketentramannya dalam kehidupan.

Empat garis besar ini merupakan penjabaran nyata diri rahmat kasih sayang Allah yang meliputi segala-galanya dan yang menandai risalah Nabi Muhammad SAW. Inilah sesungguhnya wajah dari Islam. Empat garis besar ini dalam keutuhannya menata bidang-bidang pokok dari kehidupan manusia dalam rangka mewujudkan suatu lingkungan kehidupan bersih, sehat, sejahtera, aman, damai dan bahagia lahir batin, dunia dan akhirat.

Titik awal pandangan kita adalah bahwa persoalan lingkunganhidupbukan sekedarmasalah sampah, pencemaran, pengrusakan hutan, atau pelestarian alam dan sejenisnya, melainkan ini adalah bagian dari suatu pandangan hidup itu sendiri. Sebab dalam kenyataannya, berbicaralingkungan hidup merupakan kritik terhadap kesenjangan yang diakibatkan oleh pemujian terhadap teknologi yang dalam perjalanan panjang mengakibatkan kemiskinan dan keterbelakangan yang disebabkan oleh struktur yang tidak adil dan ditunjang oleh kebijakan pembangunan yang lebihmengejar pertumbuhan ekonomi semata. Dengan kata lain, masalah lingkungan hidup bersumber dari pandangan hidup dan sikap manusia yang egosentris dalam melihat dirinya dan alam sekitarnya dengan seluruh aspek kehidupannya.

Cara pandangan inilah, norma-norma fiqh yang merupakan penjabaran dari nilai-nilai Al-Qur'an dan Al-Sunnah, sebagaimana yang dijelaskan di atas seharusnya dapat memberikan sumbangan pemikiran terhadap upaya pengembangan wawasan lingkungan hidup, atau lebih tepatnya pembangunan yang berwawasan lingkungan hidup.

Akan tetapi, harus jujur diakui bahwa sampai hari ini fiqh belum membahas wacana lingkungan hidup secara utuh dan lengkap dalam bab yang khusus. Ini tidak lain karena pada masa itu, lingkungan hidup belum menjadi masalah yang menyedot perhatian para ahli hukum Islam dan ada pengrusakan ling- kungan yang mengancam keselamatan kehidupan manusia. Kerusakan lingkungan hidup terjadi setelah alam dieksploitasi terutama untuk kepentingan industrialisasi. Eksploitasi alam terjadi secara besarbesaran setelah revolusi industri. Kini, setelah lingkungan hidup telah menjadi masalah yang sangat serius hingga mengancam kelangsungan kehidupan manusia, maka perlu dihimpun dan dirangkai sejumlah prinsip, nilai, dannorma, sertaketentuan hukum dari khazanah fiqh sebagai paradigma baru tentang lingkungan hidup.

Pemahaman masalah lingkungan hidup (fiqhalbi'ah) dan penanganannya (penyelamatan dan pelestariannya) perlu diletakkan di atas suatu fondasi moral untuk mendukung segala upaya yang sudah dilakukan dan dibina selama ini yang ternyata belum mampu mengatasi kerusakan lingkungan hidup yang sudah ada dan masih terus berlangsung. Fiqh lingkungan hidup berupaya menyadarkan manusia yang beriman supaya menginsafi bahwa masalah lingkungan hidup tidak dapat dilepaskan dari tanggung jawab manusia yang beriman dan merupakan amanat yang diembannya untukmemelihara dan melindungi alam yang dikaruniakan Sang Pencipta yang Maha Pengasih dan Penyayang sebagai hunian tempat manusia dalam menjalani hidup di bumi ini.

Manusia yang beriman dituntut untuk memfungsikan imannya dengan meyakini bahwa pemeliharaan (penyelamatan dan pelestarian) lingkungan hidup adalah juga bagian dari iman itu sendiri. Itulah wujud nyata dari statusnya sebagai khalifah di bumi, mengemban amanat dan tanggung jawab atas keamanan dan keselamatan lingkungan hidup. Lingkungan hidup harus terpelihara dengan berakibat mengancam hidupnya sendiri.

Islam berbicara mengenai hidup dan kehidupan secara umum danmendasaryang meliputialam semesta dan hari akhir atau hari depan yang berkepanjangan bagi alam raya tersebut. Fiqh berbicara mengenai realita kehidupan manusia secara rinci dan bagaimana menata kehidupan tersebut selaku bagian integral dari kehidupan itu. Dari sudut pandang inilah, fiqh ikut berbicara tentang masalah lingkungan hidup yang kini menjadi masalah dunia dan masalah kemanusiaan.

Islam sebagai panutan mayoritas rakyat Indonesia bahkan juga panutan sejumlah besar masyarakat sumbawa, banyak memberi petunjuk kepada 
masyarakat Sumbawa tentang upaya penyelamatan hidup dan eksistensi komunitas masyarakat sumbawa, baik menyangkut kehidupan pribadinya maupun kehidupan masyarakatnya ataupun kehidupan lingkungan yang lebih luas. Nilai keagamaan (Islam) menjadi hal yang penting dalam formulasi asas dan norma hukum.

Apayang dikelukan Papen Umbe ${ }^{23}$ (papen berarti Kakek dalam bahasa Sumbawa), beliau mengulas tentang nilai-nilai Islam dalam perjuangnya dengan nilai lokal Sumbawa, menurut beliau hukum adat Masyarakat Sumbawa yang telah dijiwai oleh nilainilai Islam permulaan, sehingga nilai-nilai dasar tentang kebenaran bersumber dari agama Islam, Islamlah yang menjiwai masyarakat Sumbawa dalam berpikir, bertindak dan sebagainya. Secara umum keseluruhan hukum Islam Adalah Rahmatan Lil Aalamin, dalam filosofis Sumbawa nilai Islam adalah saran menuju Kerik salamat, yaitu keselamatan dan keberkahan di dunia dan akhirat.

\section{Penutup}

Pengembangan wawasan lingkungan hidup, atau lebih tepatnya pembangunan yang berwawasan lingkungan hidup, dengan asas Rub 'u al-Munakahat, yaitu bagian yang menata hubungan manusia dalam lingkungan dan keluarga. Masyarakat sumbawa memandang bahwa persoalan lingkungan hidup bukan sekedar masalah sampah, pencemaran, pengrusakan hutan, atau pelestarian alam dan sejenisnya, melainkan ini adalah bagian dari suatu pandangan hidup itu sendiri. Dengan kata lain, masalah lingkungan hidup bersumber dari pandangan hidup dan sikap manusia yang egosentris dalam melihat dirinya dan alam sekitarnya dengan seluruh aspek kehidupannya. Cara pandangan inilah, norma-norma fiqh yang merupakan penjabaran dari nilai-nilai Al-Qur'an dan Al-Sunnah, sebagaimana yang dijelaskan di atas seharusnya dapat memberikan sumbangan pemikiran terhadap upaya pembangunan hukum berbasis ToeEkologi.

Fiqh lingkungan hidup berupaya menyadarkan manusia yang beriman supaya menginsafi bahwa masalah lingkungan hidup tidak dapat dilepaskan dari tanggung jawab manusia yang beriman, merupakan amanat untuk memelihara dan melindungi

${ }^{23}$ Peneliti berdialog dengan Papen Umbe pada Ahad siang 9 Februari 2014 alam yang dikaruniakan Allah SWT kepada manusia. Sehingga orang beriman dituntut untuk memfungsikan imannya dengan meyakini bahwa pemeliharaan (penyelamatan dan pelestarian) lingkungan hidup adalah juga bagian dari iman itu sendiri. Itulah wujud nyata dari statusnya sebagai khalifah di bumi, mengemban amanat dan tanggung jawab atas keamanan dan keselamatan lingkungan hidup. Islam sebagai panutan memberi petunjuk kepada masyarakat Sumbawa tentang upaya penyelamatan hidup dan eksistensi komunitas masyarakat sumbawa, baik menyangkut kehidupan pribadinya maupun kehidupan masyarakatnya ataupun kehidupan lingkungan yang lebih luas. Nilai keagamaan (Islam) menjadi hal yang penting dalam formulasi asas dan pembangunan hukum, menuju Kerik salamat, yaitu keselamtan dan keberkahan di dunia dan akhirat bagi tau ke tana samawa.

\section{Daftar Pustaka}

Abdul Wahab Khallaf, Kaidah-Kaidah Hukum Islam. (Bandung: Risalah, 1984)

Ali Yafie, Merintis Fiqh Lingkungan Hidup, (Jakarta: Ufuk Press, 2006)

I Dewa Gede Atmadja, Asas-Asas Pembentukan Produk Hukum, Fakultas Hukum Universitas Udayana, tanpa tahun.

J. Mc.Naughton dan Larry L. Wolf, General Ecology, (Saunders College Publishing, Second Edition, 1973)

L. J. Moleong, Metodologi Penelitian Kualitatif, (Bandung: Remaja Rasdakarya, 2000)

Lahmuddin Zuhri. Perlindungan Hak-Hak Masyarakat Atas Sumber Daya Alam (SDA) di Kabupaten Sumbawa. Jurnal Hukum Prasada. Program Magisrel Ilmu Hukum Pascasarjana Universitas Warmadewa. Denpasar. Vol 3. No 1. Hal 1-21. September 2015

Moestadji, Pelestarian Kemampuan Lingkungan Hidup, (Jakarta : Kejaksaan Agung RI, 1988)

N.H.T. Siahaan, Hukum Lingkungan dan Ekologi Pembangunan, (Jakarta : Erlangga, 2004),

Naniek Suparni, Pelestarian, Pengelolaan, dan Penegakan Hukum Lingkungan, (Jakarta : Sinar Grafika, 1994) 